\title{
SPIRAL GRAIN IN RED ALDER ${ }^{1}$ BY R. W. KENNEDY and G. K. ELLIOTT
}

\author{
R. W. KENNEDY
}

R. W. Kennedy holds a B.S. degree from State University of New York College of Forestry, and an M.F. degree from the University of British Columbia. $\mathrm{He}$ is at present studying for a Ph. D degree at Yale University. He has held summer positions with the Vancouver Laboratory of the Forest Products Laboratory of Canada; with the New York College of Forestry on a chemical debarking project; and with the Forest Pathology Laboratory at Saskatoon, Sask.

\section{G. K. ELLIOTT}

G. K. Elliott holds a B.Sc. (For.) degree from the University of Wales and is at present studying for an M.F. degree at the University of British Columbia. He has held summer positions with the Vancouver Laboratory of the Forest Products Laboratory of Canada, and with the British Forestry Commission in Wales.

\section{ABSTRACT}

The occurrence and severity of spiral grain in red alder (Alnus rubra Bong.) on two sites, one poor and the other high-medium, was investigated. The changing spiral from pith to bark was measured at breast height and at 10-foot intervals above the ground. No straight-grained tree was found on either site. Individual trees varied greatly in both the pattern and intensity of their spirality.

\section{INTRODUCTION}

Spiral grain in wood may cause severe twisting of lumber and veneer. In the primary forest products industries the presence of spiral grain in the tree results in cross-grained products. The effect of cross-grain on the strength properties of wood is well known. A grain deviation of 1 in $25\left(2^{\circ} 18^{\prime}\right)$ results in decreased tensile strength, whereas a slope of 1 in $10\left(5^{\circ} 43^{\prime}\right)$ will markedly reduce as well the strength of timber in compression (6).

In a concurrent project, so far unreported, of 502 cross-sections examined for spiral grain, only two had perfectly straight grain. The remaining 500 sections had spirals ranging from $1 / 2^{\circ}$ to $20^{\circ}$. Although the occurrence of spiral grain seems to be universal, observations have shown its intensity to be quite variable. When and if factors influencing the intensity of spiral are understood, it is possible that its severity might be controlled by silvicultural and genetical means. With this in mind, red alder (Alnus rubra Bong.) trees growing on two different sites were examined for spirality, and the resulting measurements were correlated with the factors of height, diameter, and age.

\footnotetext{
${ }^{1}$ A contribution from the Vancouver Laboratory, Forest Products Laboratories of Canada, a Division of the Forestry Branch, Department of Northern Affairs and National Resources, Canada. Received for publication December 17, 1956.
} 
TABLE 1

Correlation Coefficieints Between Radius, Age and Cumulative Absolute Spiral Angle

\begin{tabular}{|c|c|c|c|}
\hline Classification & Statistic & $\begin{array}{c}\text { Locality } \\
1\end{array}$ & $\begin{array}{c}\text { Locality } \\
2\end{array}$ \\
\hline Zero & ${ }^{\text {Ispiral.radius }}$ & $0.65^{1}$ & $0.51^{1}$ \\
\hline Order & rradius.age & $0.89^{t}$ & $0.87^{1}$ \\
\hline Correlations & ${ }^{\text {rspiral.age }}$ & $0.67^{1}$ & $0.60^{x}$ \\
\hline $\begin{array}{l}\text { Multiple } \\
\text { Correlation }\end{array}$ & ${ }^{\text {Ispiral.radius age }}$ & $0.67^{1}$ & $0.60^{\mathrm{t}}$ \\
\hline $\begin{array}{l}\text { Partial } \\
\text { Correlations }\end{array}$ & $\begin{array}{l}{ }^{{ }^{I}} \text { spiral radius.age } \\
{ }^{\mathrm{I}} \text { spiral age.radius }\end{array}$ & $\begin{array}{l}0.16 \\
0.26^{3}\end{array}$ & $\begin{array}{c}-0.03 \\
0.35^{2}\end{array}$ \\
\hline
\end{tabular}

${ }^{3}$ Significant at the $0.1 \%$ level.

${ }^{2}$ Significant at the $1 \%$ level.

${ }^{B}$ Significant at the $10 \%$ level.

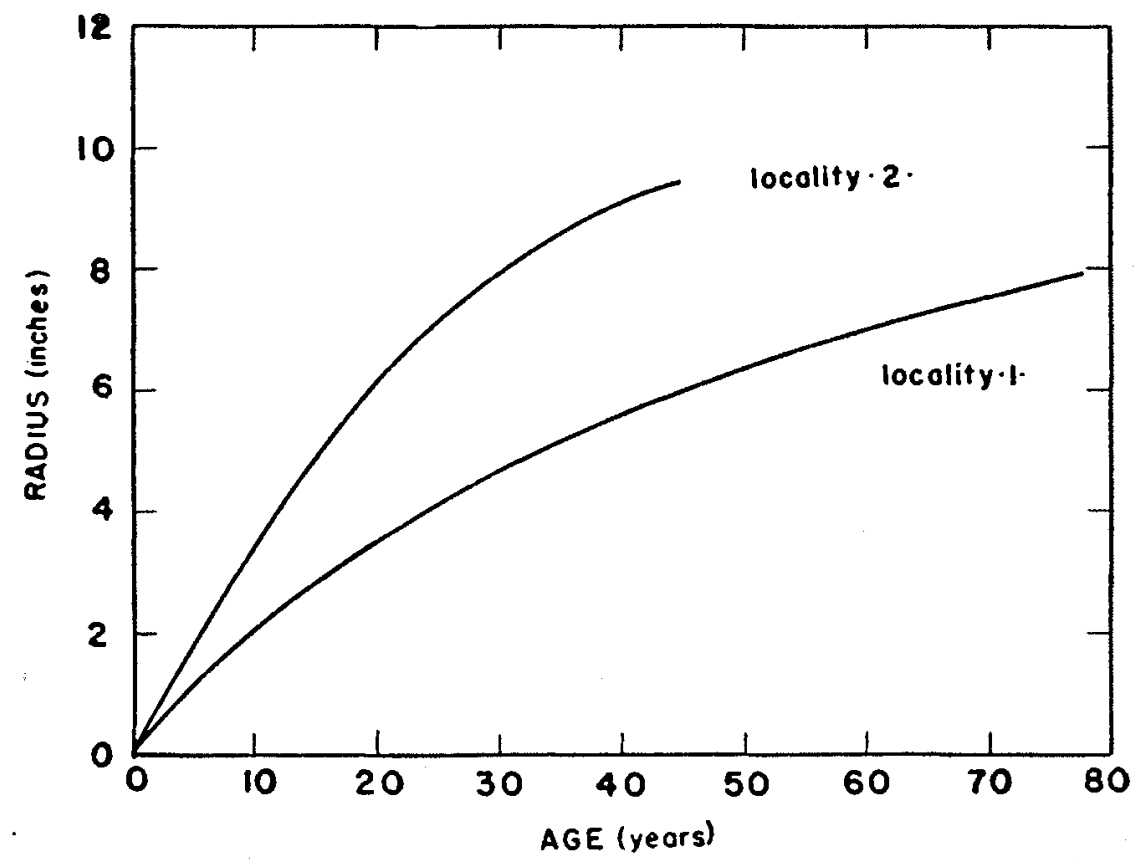

FIGURE 1. Relation Between Radius and Age At B.H. Level. 


\section{Materials and Methods}

On each of two sites, 13 red alder trees were felled and cross-sections removed at breast height and at ten-foot intervals above ground level. The oldest trees were sampled within the limits of the populations on each site. Locality 1 had a site index of 73 at 50 years of age, while Locality 2 had a site index of $101 .^{2}$ According to British Columbia Forest Service yield tables (3), these areas represented a low poor and a high medium site, respectively. The difference between the two sites is reflected further in the radius-age curves of Figure 1, which show that the trees on Locality 2 have the faster rate of growth.

TABLE II

Table of Spirals Recorded at the Breast Height LEVEL in all TREes From Locality 1

\begin{tabular}{|c|c|c|c|c|c|}
\hline $\begin{array}{c}\text { Tree } \\
\text { Number }\end{array}$ & $\begin{array}{l}\text { Age from } \\
\text { Pith }\end{array}$ & $\begin{array}{l}\text { Radius in } \\
\text { Inches }\end{array}$ & $\begin{array}{l}\text { Actu: } \\
\text { Spira } \\
\text { Degre }\end{array}$ & & $\begin{array}{c}\text { Cumulative } \\
\text { Spiral } \\
\text { Degrees }\end{array}$ \\
\hline \multirow{7}{*}{1} & 0 & 0 & 0 & & 0 \\
\hline & 10 & 0.8 & 4.0 & $\mathbf{R}$ & 4.0 \\
\hline & 20 & 1.8 & 4.0 & $\mathrm{R}$ & 4.0 \\
\hline & 30 & 2.7 & 4.0 & $\mathbf{R}$ & 4.0 \\
\hline & 40 & 3.6 & 4.0 & $\mathbf{R}$ & 4.0 \\
\hline & 50 & 4.3 & 4.0 & $\mathbf{R}$ & 4.0 \\
\hline & 53 & 4.4 & 4.0 & $\mathrm{R}$ & 4.0 \\
\hline \multirow{7}{*}{2} & 0 & 0 & 0 & & 0 \\
\hline & 10 & 1.0 & 1.0 & $\mathbf{L}$ & 1.0 \\
\hline & 20 & 2.1 & 2.75 & $\bar{L}$ & 2.75 \\
\hline & 30 & 3.1 & 4.0 & $\bar{L}$ & 4.0 \\
\hline & 40 & 4.2 & 5.0 & $\mathrm{~L}$ & 5.0 \\
\hline & 50 & 4.7 & 6.0 & $\mathbf{L}$ & 6.0 \\
\hline & 54 & 5.2 & 6.0 & $\mathrm{~L}$ & 6.0 \\
\hline \multirow{7}{*}{3} & 0 & 0 & 0 & & 0 \\
\hline & 10 & 1.7 & 1.75 & $\mathbf{L}$ & 1.75 \\
\hline & 20 & 2.4 & 3.75 & $\mathrm{~L}$ & 3.75 \\
\hline & 30 & 3.7 & 6.0 & $\mathrm{~L}$ & 6.0 \\
\hline & 40 & 4.7 & 8.0 & $\mathrm{~L}$ & 8.0 \\
\hline & 50 & 6.1 & 10.0 & $\mathrm{~L}$ & 10.0 \\
\hline & 52 & 6.2 & 10.25 & $\mathrm{~L}$ & 10.0 \\
\hline \multirow{7}{*}{4} & 0 & 0 & 0 & & 0 \\
\hline & 10 & 0.8 & 1.0 & $\mathbf{R}$ & 1.0 \\
\hline & 20 & 1.6 & 0.5 & $\mathrm{~L}$ & 2.5 \\
\hline & 30 & 2.3 & 2.0 & $\mathrm{~L}$ & 3.0 \\
\hline & 40 & 3.1 & 2.25 & $\mathbf{L}$ & 3.25 \\
\hline & 50 & 3.9 & 2.25 & $\mathrm{~L}$ & 3.25 \\
\hline & 52 & 4.0 & 2.25 & $\bar{L}$ & 3.25 \\
\hline
\end{tabular}

${ }^{9}$ Site Index: Height in feet, of the average dominant and co-dominant trees at the age of 50 years, used as an indicator of site quality. 
SEPTEMBER, 1957

TABLE II (Cont'd)

\begin{tabular}{|c|c|c|c|c|}
\hline $\begin{array}{c}\text { Tree } \\
\text { Number }\end{array}$ & $\begin{array}{c}\text { Age from } \\
\text { Pith }\end{array}$ & $\begin{array}{l}\text { Radius in } \\
\text { Inches }\end{array}$ & $\begin{array}{c}\text { Actual } \\
\text { Spiral } \\
\text { Degrees }\end{array}$ & $\begin{array}{c}\text { Cumulative } \\
\text { Spiral } \\
\text { Degrees }\end{array}$ \\
\hline \multirow{6}{*}{5} & 0 & 0 & 0 & 0 \\
\hline & 10 & 1.2 & $1.75 \mathrm{~L}$ & 1.75 \\
\hline & 20 & 2.5 & $0.5 \mathrm{~L}$ & 4.0 \\
\hline & 30 & 3.7 & $2.0 \quad \mathrm{~L}$ & 5.5 \\
\hline & 40 & 5.0 & $4.0 \mathrm{~L}$ & 7.5 \\
\hline & 50 & 6.1 & $5.25 \mathrm{~L}$ & 8.75 \\
\hline \multirow{9}{*}{6} & 0 & 0 & 0 & 0 \\
\hline & 10 & 1.0 & $2.0 \mathrm{R}$ & 2.0 \\
\hline & 20 & 2.0 & $0.5 \quad \mathbf{R}$ & 3.5 \\
\hline & 30 & 3.0 & $0.75 \mathrm{R}$ & 4.75 \\
\hline & 40 & 4.0 & $2.0 \mathrm{~L}$ & 6.0 \\
\hline & 50 & 5.0 & $3.75 \mathrm{~L}$ & 7.75 \\
\hline & 60 & 6.1 & $4.25 \mathrm{~L}$ & 8.25 \\
\hline & 70 & 7.1 & $6.0 \mathrm{~L}$ & 10.0 \\
\hline & 80 & 8.1 & $6.75 \mathrm{~L}$ & 10.75 \\
\hline \multirow{9}{*}{7} & 0 & 0 & 0 & 0 \\
\hline & 10 & 0.7 & $1.75 \mathrm{~L}$ & 1.75 \\
\hline & 20 & 1.5 & $2.0 \mathrm{~L}$ & 2.0 \\
\hline & 30 & 2.2 & $3.75 \mathrm{~L}$ & 3.75 \\
\hline & 40 & 3.0 & $5.0 \mathrm{~L}$ & 5.0 \\
\hline & 50 & 3.8 & $6.25 \mathrm{~L}$ & 6.25 \\
\hline & 60 & 4.6 & $7.5 \mathrm{~L}$ & 7.5 \\
\hline & 70 & 5.3 & $8.75 \mathrm{~L}$ & 8.75 \\
\hline & 77 & 6.1 & $9.25 \mathrm{~L}$ & 9.25 \\
\hline \multirow{9}{*}{8} & 0 & 0 & 0 & 0 \\
\hline & 10 & 1.0 & $1.75 \mathrm{~L}$ & 1.75 \\
\hline & 20 & 2.0 & $2.25 \mathrm{~L}$ & 2.25 \\
\hline & 30 & 2.9 & $4.0 \mathrm{~L}$ & 4.0 \\
\hline & 40 & 3.9 & $6.0 \mathrm{~L}$ & 6.0 \\
\hline & 50 & 4.7 & $8.25 \mathrm{~L}$ & 8.25 \\
\hline & 60 & 5.8 & $10.0 \mathrm{~L}$ & 10.0 \\
\hline & 70 & 6.8 & $11.75 \mathrm{~L}$ & 11.75 \\
\hline & 77 & 7.5 & $12.25 \mathrm{~L}$ & 12.25 \\
\hline \multirow{7}{*}{9} & 0 & 0 & 0 & 0 \\
\hline & 10 & 0.8 & 0 & 0 \\
\hline & 20 & 1.6 & 0 & 0 \\
\hline & 30 & 2.5 & 0 & 0 \\
\hline & 40 & 3.3 & 0 & 0 \\
\hline & 50 & 4.1 & 0 & 0 \\
\hline & 60 & 5.0 & 0 & 0 \\
\hline
\end{tabular}


TABLE II (Cont'd)

\begin{tabular}{|c|c|c|c|c|}
\hline $\begin{array}{c}\text { Tree } \\
\text { Number }\end{array}$ & $\begin{array}{l}\text { Age from } \\
\text { Pith }\end{array}$ & $\begin{array}{l}\text { Radius in } \\
\text { Inches }\end{array}$ & $\begin{array}{c}\text { Actual } \\
\text { Spiral } \\
\text { Degrees }\end{array}$ & $\begin{array}{c}\text { Cumulative } \\
\text { Spiral } \\
\text { Degrees }\end{array}$ \\
\hline \multirow{9}{*}{10} & 0 & 0 & & 0 \\
\hline & 10 & 1.1 & $1.75 \mathrm{~L}$ & 1.75 \\
\hline & 20 & 2.1 & $3.5 \mathrm{~L}$ & 3.5 \\
\hline & 30 & 3.1 & $6.75 \mathrm{~L}$ & 6.75 \\
\hline & 40 & 4.2 & $13.0 \mathrm{~L}$ & 13.0 \\
\hline & 50 & 5.3 & $16.0 \mathrm{~L}$ & 16.0 \\
\hline & 60 & 6.3 & $18.0 \mathrm{~L}$ & 18.0 \\
\hline & 70 & 7.4 & $20.75 \mathrm{~L}$ & 20.75 \\
\hline & 80 & 8.5 & $22.0 \mathrm{~L}$ & 22.0 \\
\hline \multirow{7}{*}{11} & 0 & 0 & 0 & 0 \\
\hline & 10 & 1.5 & $0.75 \mathrm{~L}$ & 0.75 \\
\hline & 20 & 3.0 & $2.0 \mathrm{~L}$ & 2.0 \\
\hline & 30 & 4.3 & $3.75 \mathrm{~L}$ & 3.75 \\
\hline & 40 & 5.9 & $4.25 \mathrm{~L}$ & 4.25 \\
\hline & 50 & 7.3 & $6.0 \mathrm{~L}$ & 6.0 \\
\hline & 54 & 8.0 & $6.25 \mathrm{~L}$ & 6.25 \\
\hline \multirow{7}{*}{12} & 0 & 0 & 0 & 0 \\
\hline & 10 & 1.3 & $0.25 \mathrm{~L}$ & 0.25 \\
\hline & 20 & 2.5 & $2.0 \mathrm{~L}$ & 2.0 \\
\hline & 30 & 3.8 & $3.75 \mathrm{~L}$ & 3.75 \\
\hline & 40 & 5.0 & $4.25 \mathrm{~L}$ & 4.25 \\
\hline & 50 & 6.3 & $5.25 \mathrm{~L}$ & 5.25 \\
\hline & 53 & 6.4 & $5.5 \mathrm{~L}$ & 5.5 \\
\hline \multirow{8}{*}{13} & 0 & 0 & 0 & 0 \\
\hline & 10 & 0.7 & $2.0 \mathrm{~L}$ & 2.0 \\
\hline & 20 & 1.8 & $3.75 \mathrm{~L}$ & 3.75 \\
\hline & 30 & 2.0 & $4.75 \bar{L}$ & 4.75 \\
\hline & 40 & 2.9 & $6.5 \mathrm{~L}$ & 6.5 \\
\hline & 50 & 3.5 & $8.0 \quad \overline{\mathrm{L}}$ & 8.0 \\
\hline & 60 & 4.2 & $9.5 \mathrm{~L}$ & 9.5 \\
\hline & 70 & 5.0 & $11.0 \mathrm{~L}$ & 11.0 \\
\hline
\end{tabular}

The object of this investigation was to obtain an indication of the spiral pattern throughout the life of the tree. Each section was split along a diameter with a straight-edged wedge. The split followed the grain, exposing the spiral pattern. This operation was done while the section was in the green condition to prevent possible spiral changes due to differential shrinkage. The spiral was measured at ten-year intervals from the pith on each section, and the radius corresponding to each measurement was recorded.

The pith of each cross-section was chosen as the reference line from which the spiral determinations were compared. Actual spiral measurements 
TABLE III

Table of Spirals Recorded at The Breast Height Level in all Trees From Locality 2

\begin{tabular}{|c|c|c|c|c|c|}
\hline $\begin{array}{c}\text { Tree } \\
\text { Number }\end{array}$ & $\begin{array}{c}\text { Age from } \\
\text { Pith }\end{array}$ & $\begin{array}{l}\text { Radius in } \\
\text { Inches }\end{array}$ & $\begin{array}{r}\text { Actual } \\
\text { Spiral } \\
\text { Degree }\end{array}$ & & $\begin{array}{c}\text { Cumulative } \\
\text { Spiral } \\
\text { Degrees }\end{array}$ \\
\hline \multirow{6}{*}{1} & 0 & 0 & 0 & & 0 \\
\hline & 10 & 2.1 & 0 & & 0 \\
\hline & 20 & 6.0 & 1.5 & L & 1.5 \\
\hline & 30 & 9.8 & 2.0 & L & 2.0 \\
\hline & 40 & 12.3 & 4.5 & $\mathbf{L}$ & 4.5 \\
\hline & 50 & 13.6 & 6.0 & $\mathrm{~L}$ & 6.0 \\
\hline \multirow{5}{*}{2} & 0 & 0 & 0 & & 0 \\
\hline & 10 & 3.7 & 1.5 & $\mathbf{R}$ & 1.5 \\
\hline & 20 & 6.0 & 2.5 & $\mathbf{L}$ & 4.0 \\
\hline & 30 & 7.8 & 5.5 & $\mathbf{L}$ & 7.0 \\
\hline & 40 & 10.0 & 6.5 & $\mathbf{L}$ & 8.0 \\
\hline \multirow{6}{*}{3} & 0 & 0 & 0 & & 0 \\
\hline & 10 & 3.5 & 0.25 & $\mathbf{L}$ & 0.25 \\
\hline & 20 & 5.8 & 0.5 & $\mathrm{R}$ & 0.75 \\
\hline & 30 & 8.4 & 2.0 & $\mathbf{R}$ & 2.5 \\
\hline & 40 & 9.5 & 2.0 & $\mathbf{R}$ & 2.5 \\
\hline & 45 & 10.2 & 1.75 & $\mathbf{R}$ & 2.75 \\
\hline \multirow{6}{*}{4} & 0 & 0 & 0 & & 0 \\
\hline & 10 & 4.1 & 1.25 & $\mathbf{L}$ & 1.25 \\
\hline & 20 & 6.6 & 0.25 & $\mathbf{L}$ & 2.25 \\
\hline & 30 & 7.8 & 1.25 & $\mathbf{L}$ & 3.25 \\
\hline & 40 & 8.4 & 1.75 & $\mathbf{L}$ & 3.75 \\
\hline & 44 & 8.5 & 1.75 & $\mathrm{~L}$ & 3.75 \\
\hline \multirow{6}{*}{5} & 0 & 0 & 0 & & 0 \\
\hline & 10 & 4.9 & 0.5 & $\mathbf{L}$ & 0.5 \\
\hline & 20 & 7.3 & 4.5 & $\mathbf{R}$ & 5.0 \\
\hline & 30 & 8.8 & 1.75 & $\mathrm{R}$ & 7.25 \\
\hline & 40 & 10.0 & 1.75 & $\mathbf{R}$ & 7.25 \\
\hline & 44 & 10.4 & 0.5 & $\mathbf{R}$ & 8.5 \\
\hline \multirow{6}{*}{6} & 0 & 0 & 0 & & 0 \\
\hline & 10 & 3.5 & 2.5 & $\mathrm{R}$ & 2.5 \\
\hline & 20 & 5.0 & 1.75 & $\mathrm{R}$ & 3.25 \\
\hline & 30 & 6.2 & 0.75 & $\mathrm{R}$ & 4.25 \\
\hline & 40 & 7.0 & 0.5 & $\mathbf{R}$ & 4.25 \\
\hline & 43 & 7.3 & 0.75 & $\mathrm{R}$ & 4.75 \\
\hline \multirow{5}{*}{7} & 0 & 0 & 0 & & 0 \\
\hline & 10 & 3.7 & 1.0 & $\mathrm{R}$ & 1.0 \\
\hline & 20 & 7.2 & 2.0 & $\mathbf{R}$ & 2.0 \\
\hline & 30 & 9.2 & 2.25 & $\mathbf{R}$ & 2.25 \\
\hline & 40 & 11.2 & 2.75 & $\mathrm{R}$ & 2.75 \\
\hline
\end{tabular}


TABLE III (Cont'd)

\begin{tabular}{|c|c|c|c|c|c|}
\hline$\underset{\text { Number }}{\text { Tree }}$ & $\begin{array}{l}\text { Age from } \\
\text { Pith }\end{array}$ & $\begin{array}{l}\text { Radius in } \\
\text { Inches }\end{array}$ & $\begin{array}{r}\text { Actual } \\
\text { Spiral } \\
\text { Degree }\end{array}$ & & $\begin{array}{c}\text { Cumulative } \\
\text { Spiral } \\
\text { Degrees } \\
\end{array}$ \\
\hline \multirow{6}{*}{8} & 0 & 0 & 0 & & 0 \\
\hline & 10 & 3.0 & 1.5 & $\mathbf{R}$ & 1.5 \\
\hline & 20 & 4.8 & 0 & & 3.0 \\
\hline & 30 & 6.2 & 0.75 & $\mathrm{~L}$ & 3.75 \\
\hline & 40 & 7.0 & 1.5 & L & 4.5 \\
\hline & 45 & 7.4 & 2.0 & $\mathbf{L}$ & 5.0 \\
\hline \multirow{6}{*}{9} & 0 & 0 & 0 & & 0 \\
\hline & 10 & 4.6 & 1.5 & $\mathrm{R}$ & 1.5 \\
\hline & 20 & 6.8 & 1.0 & $\mathbf{R}$ & 2.0 \\
\hline & 30 & 8.5 & 2.751 & $\mathrm{R}$ & 5.75 \\
\hline & 40 & 9.6 & 1.0 & $\mathrm{~L}$ & 7.5 \\
\hline & 46 & 9.8 & 1.0 & $\mathrm{~L}$ & 7.5 \\
\hline \multirow{6}{*}{10} & 0 & 0 & 0 & & 0 \\
\hline & 10 & 4.0 & $4.5 \mathrm{I}$ & $\mathbf{R}$ & 4.5 \\
\hline & 20 & 5.9 & 1.75 & $\mathbf{R}$ & 7.25 \\
\hline & 30 & 7.4 & 0.25 & $\mathrm{~L}$ & 9.25 \\
\hline & 40 & 8.2 & 1.25 & $\mathrm{~L}$ & 10.25 \\
\hline & 42 & 8.4 & 1.25 & $\mathrm{~L}$ & 10.25 \\
\hline \multirow{6}{*}{11} & 0 & 0 & 0 & & 0 \\
\hline & 10 & 3.7 & $2.75 \mathrm{I}$ & $\mathrm{R}$ & 2.75 \\
\hline & 20 & 5.6 & 4.75 & $\mathbf{R}$ & 4.75 \\
\hline & 30 & 7.7 & $4.25 \mathrm{I}$ & $\mathrm{R}$ & 5.25 \\
\hline & 40 & 8.8 & 4.01 & $\mathrm{R}$ & 5.5 \\
\hline & 45 & 9.1 & 4.0 & $\mathrm{R}$ & 5.5 \\
\hline \multirow{6}{*}{12} & 0 & 0 & 0 & & 0 \\
\hline & 10 & 3.1 & $4.0 \mathrm{I}$ & $\mathbf{R}$ & 4.0 \\
\hline & 20 & 5.0 & 3.75 & $\mathbf{R}$ & 4.25 \\
\hline & 30 & 6.8 & $4.0 \mathrm{I}$ & $\mathrm{R}$ & 4.5 \\
\hline & 40 & 7.9 & $3.25 \mathrm{I}$ & $\mathrm{R}$ & 5.25 \\
\hline & 42 & 8.2 & 3.25 & $\mathbf{R}$ & 5.25 \\
\hline \multirow{6}{*}{13} & 0 & 0 & 0 & & 0 \\
\hline & 10 & 3.7 & $4.25 \mathrm{I}$ & $\mathrm{R}$ & 4.25 \\
\hline & 20 & 6.4 & 7.0 & $\mathbf{R}$ & 7.0 \\
\hline & 30 & 8.4 & $8.5 \mathrm{I}$ & $\mathrm{R}$ & 8.5 \\
\hline & 40 & 8.6 & 9.0 & $\mathrm{R}$ & 9.0 \\
\hline & 42 & 9.4 & 9.0 & $\mathrm{R}$ & 9.0 \\
\hline
\end{tabular}

were made with a modified level protractor (Figure 2), accurate to within $1 / 2^{\circ}$. The knife edge was placed firmly on the pith, and at each decade the angle of the grain was measured either as a right or left deviation from the axis of the pith, by means of the adjustable protractor. Readings from cor- 


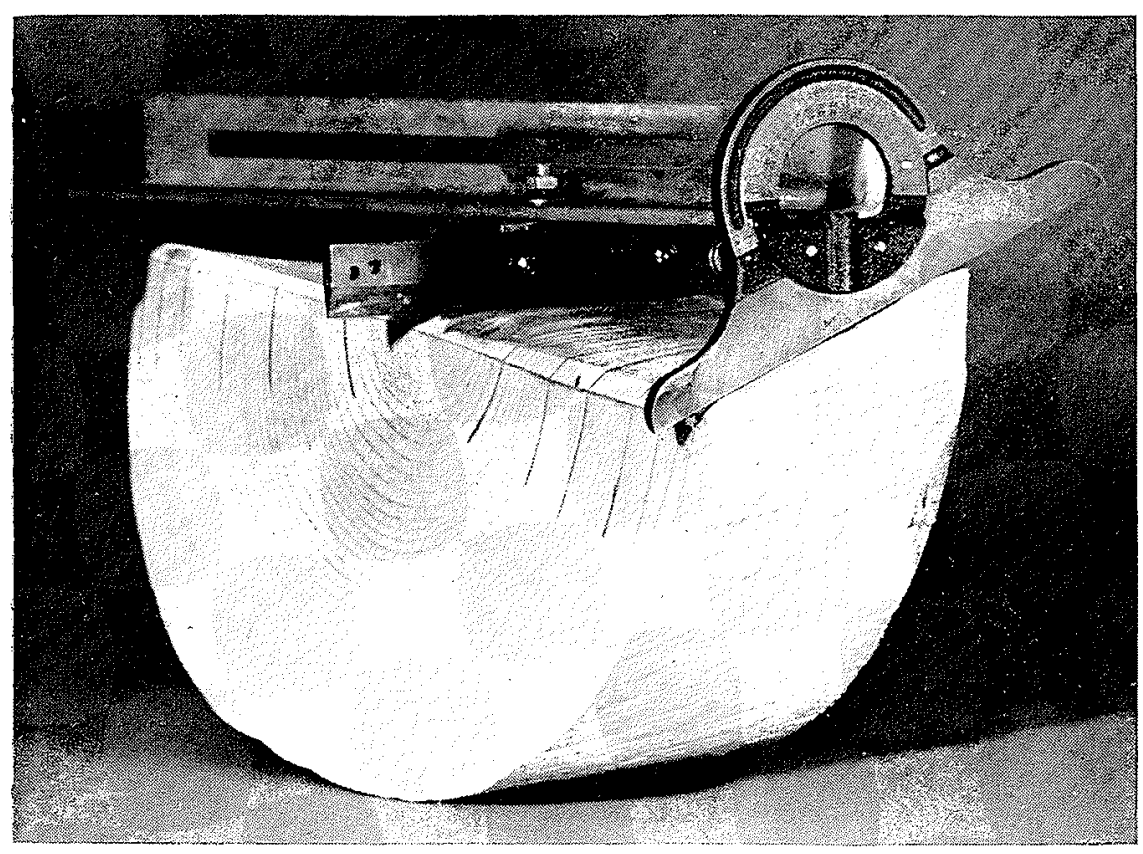

FIGURE 2. Method of Measuring Spiral Grain.

responding rings on either side of the pith were averaged to give the mean spiral and radius for every tenth increment.

\section{Results}

On both sites, the trees exhibited a tendency to spiral to the right in youth with a change in spiral toward the left with advancing age. Some trees never exhibited an initial right spiral, but instead increased their left-hand spiral throughout life. Similarly, some trees displayed such a high initial right-hand spiral that an actual left spiral was never attained, although the large right-hand spiral decreased toward the left with age. Only in a few scattered instances did a section show a continually increasing right spiral from pith to bark. Tables 2 and 3 show the actual spirals recorded at the B.H. level, for all trees from localities 1 and 2 respectively.

Height in the tree appeared to influence spirality, at least in the Locality 1 material. Height also affected spirality within the same annual increment in much the same manner. The effect of height in the good-site trees is uncertain, because, in part, this material was younger and showed fewer spiral contours.

Eight western hemlock trees (Tsuga heterophylla (Raf.) Sarg.) growing on the same site as the poorer alders were analyzed for spiral pattern. It is interesting to note that these trees had a general spiral pattern exactly the 


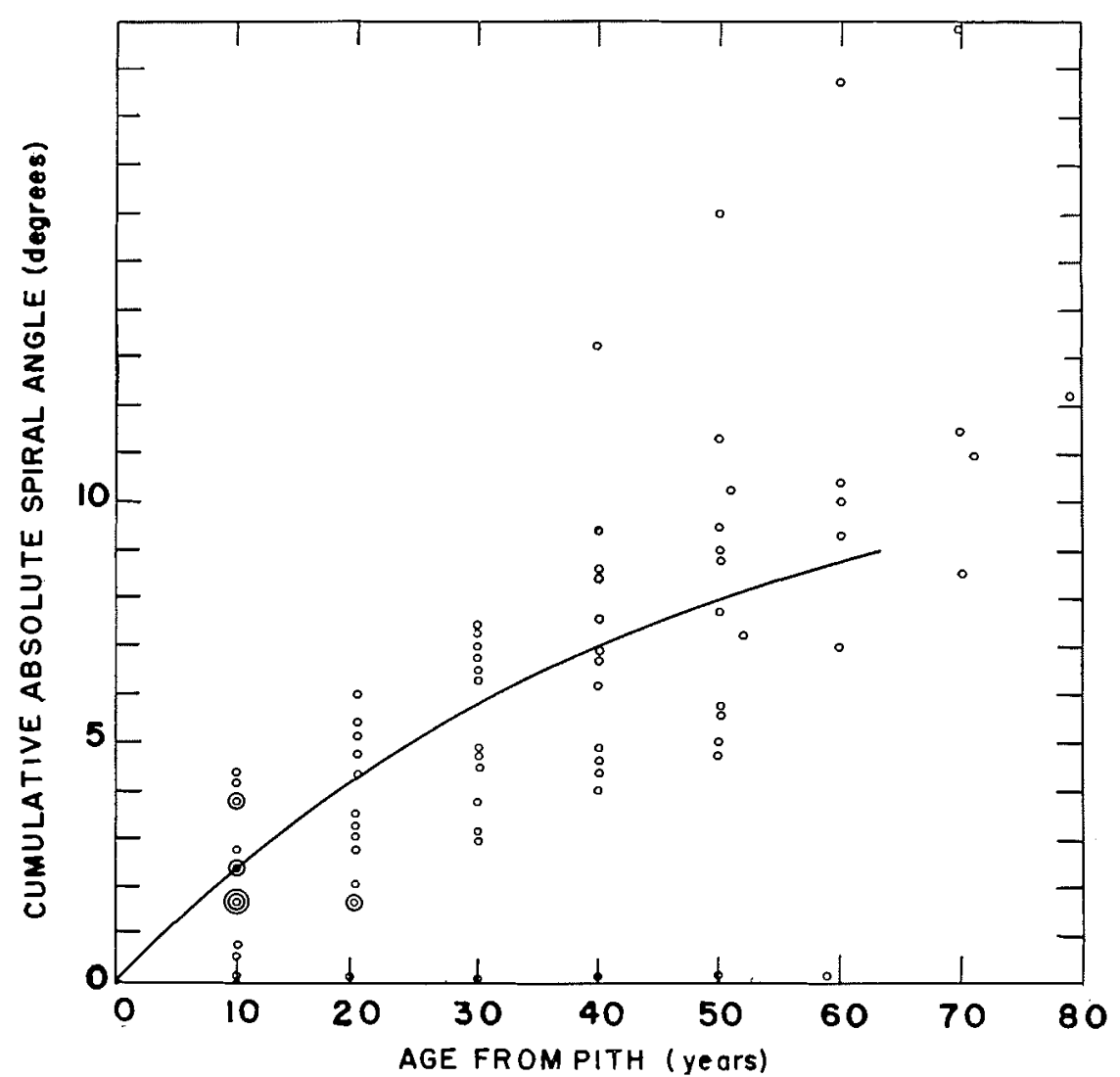

FIGURE 3. Relation Between Age and Cumulative Absolute Spiral Angle at The B.H. Level: Locality 1.

opposite to that of the red alder growing in the same immediate area. The hemlock had an initial left spiral, which changed to a right spiral with increasing age. This is consistent with the most usual pattern observed in two other coniferous species-Douglas fir (Pseudotsuga menziesii (Mirb.) Franco) and lodgepole pine (Pinus contorta Dougl.) (5).

\section{Effect of Age and Diameter on Spirality Between Sites}

Figures 3 and 4 show graphically the effect of age on spiral angle at the B.H. level. A new concept is introduced in these curves-that of absolute spiral angle. By this method of expression, the direction of the spirality is ignored. This is a valid argument from the practical point of view, since only the absolute degree of spirality affects timber properties. Furthermore, the 


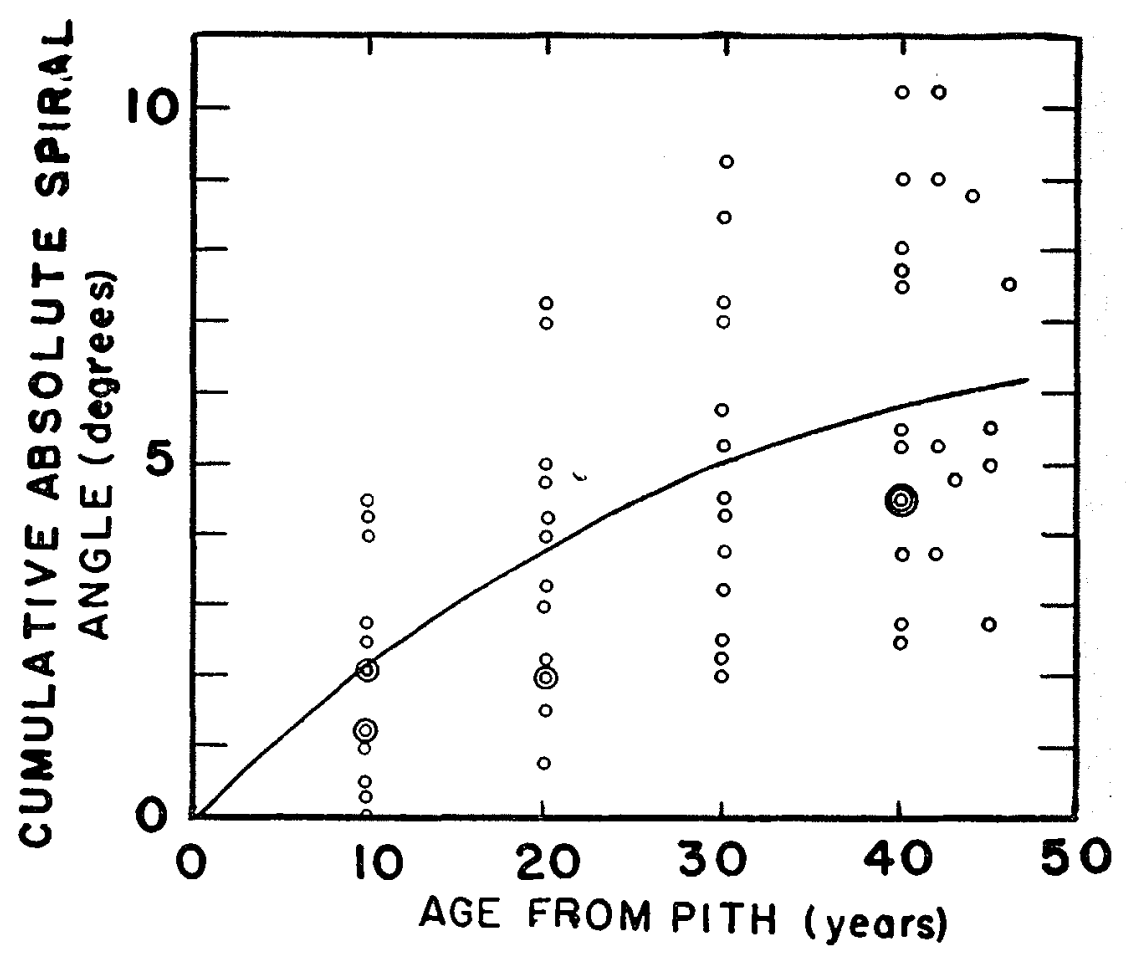

FIGURE 4. Relation Between Age And Cumulative Absolute Spiral Angle At B.H.: Locality 2.

absolute spiral angle at any point was plotted as a cumulative figure, representing the total number of degrees through which the spiral had progressed from the pith. Tables 2 and 3 show the cumulative figures, calculated from the actual angle measured. For example, if a tree had a $4^{\circ}$ right spiral at 10 years, and changed steadily to a $5^{\circ}$ left spiral at 50 years, the cumulative absolute spiral angle would equal $9^{\circ}$ at 50 years.

The average lines drawn in Figures 3 and 4 are slightly curvilinear in nature and show that spiral angle changes most rapidly in youth and at a decreasing rate thereafter.

At comparable ages, the cumulative absolute spiral angle which had developed in the Locality 1 trees was only slightly greater than that in Locality 2. For example, at 40 years of age, the average angles developed were $7^{\circ}$ and $5.75^{\circ}$ for the poor- and good-site trees, respectively. Figure 1 shows that at 40 years of age, the average radii for the two sites were 5.4 and 9.0 inches. Although average tree diameter is quite different at a given age between the two site classes, spirality was found to be similar. 


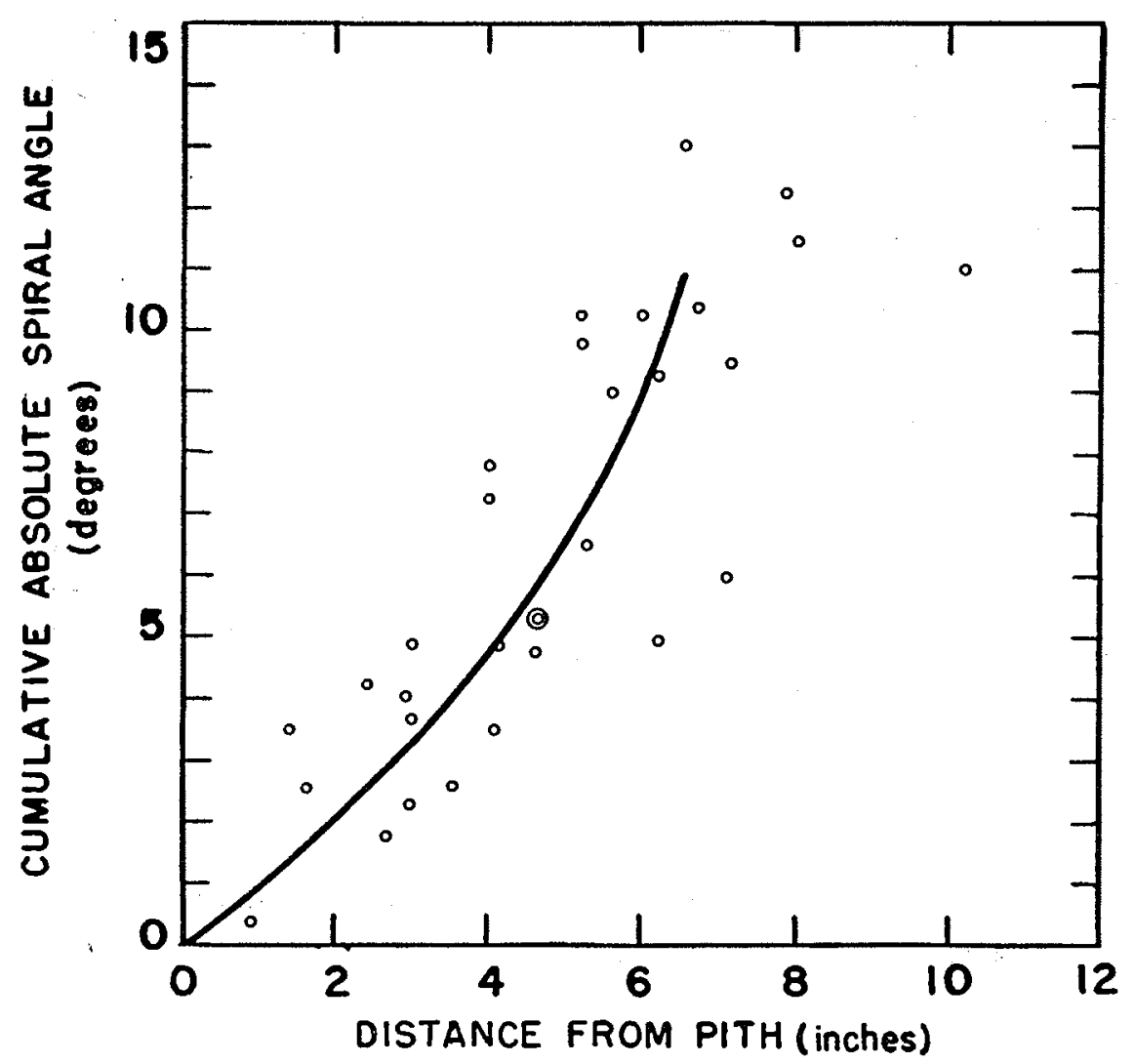

FIGURE 5. Relation Between Radius and Cumulative Absolute Spiral Angle At The B.H. Level: Locality 1.

Because spiral angle varied with age from the pith, it also changed with distance from pith in inches (radius). Figures 5 and 6 indicate the influence of radius on cumulative absolute spiral angle. At comparable radii, the cumulative absolute spiral angle developed in the poor-site trees was much larger than that in the good-site material. For example, at 6 inches from the pith, the average angles developed were $3.5^{\circ}$ and $9^{\circ}$ for the good- and poorsite trees. respectively. This wide variation can be explained by reference to Figure 1. At a. 6 -inch radius, the Locality 2 trees were only 20 years old, whereas the Locality 1 trees had attained an age of 50 years. The influence of age on spiral has already been pointed out; it is this factor which is responsible for the large difference in spiral when the good-and poor-site trees are compared at equal distances from the pith. 


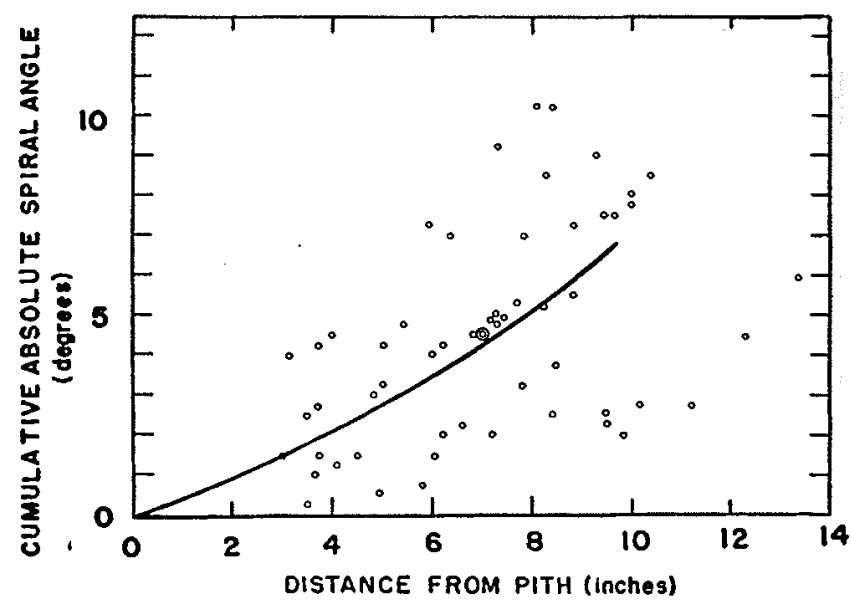

FIGURE 6. Relation Between Radius and Cumulative Absolute Spiral Angle At The B.H. Level in Locality 2.

\section{Effect of Age and Diameter on Spirality Within a Site}

These findings demonstrate that most of the difference in spiral angle between the two sites may be attributed to age. It is not known, however, whether age or radius is the more important factor in controlling spirality within a site. The data at B. H. level were subjected to a complete statistical correlation analysis to determine the relative importance of age and radius on cumulative absolute spiral angle. The correlation coefficients obtained in this analysis are presented in Table 1.

The results of the statistical analysis are summarized as follows:

(1) All zero-order or simple correlation coefficients were highly significant. Radius and all other factors linearly associated with it were highly correlated with spirality ( $r=0.65$ for Locality 1 and 0.51 for Locality 2 ). Similarly, age and all other linearly correlated terms were associated to a high degree with cumulative absolute spiral angle $(r=0.67$ and 0.60$)$.

(2) As a result of age and radius being very highly correlated ( $r=0.89$ and 0.87 ), the multiple correlation coefficient (the joint effect of age and radius on spiral) was no higher than age or radius acting individually in simple correlations.

(3) The relative importance of radius and age on cumulative absolute spiral angle can be seen by comparing partial correlation coefficients. The effect of radius on spiral (with age held constant) is small and nonsignificant ( $r=0.16$ and -0.03 ). However, the effect of age on spiral (with radius held constant) is significant ( $r=0.26$ and 0.35 ).

The fact that radius and spirality do not continue to vary together when age is constant is borne out by the non-significant partial correlation coefficients. Therefore, most of the apparent relation between radius and spiral is attributable to these variables being commonly associated with age. 


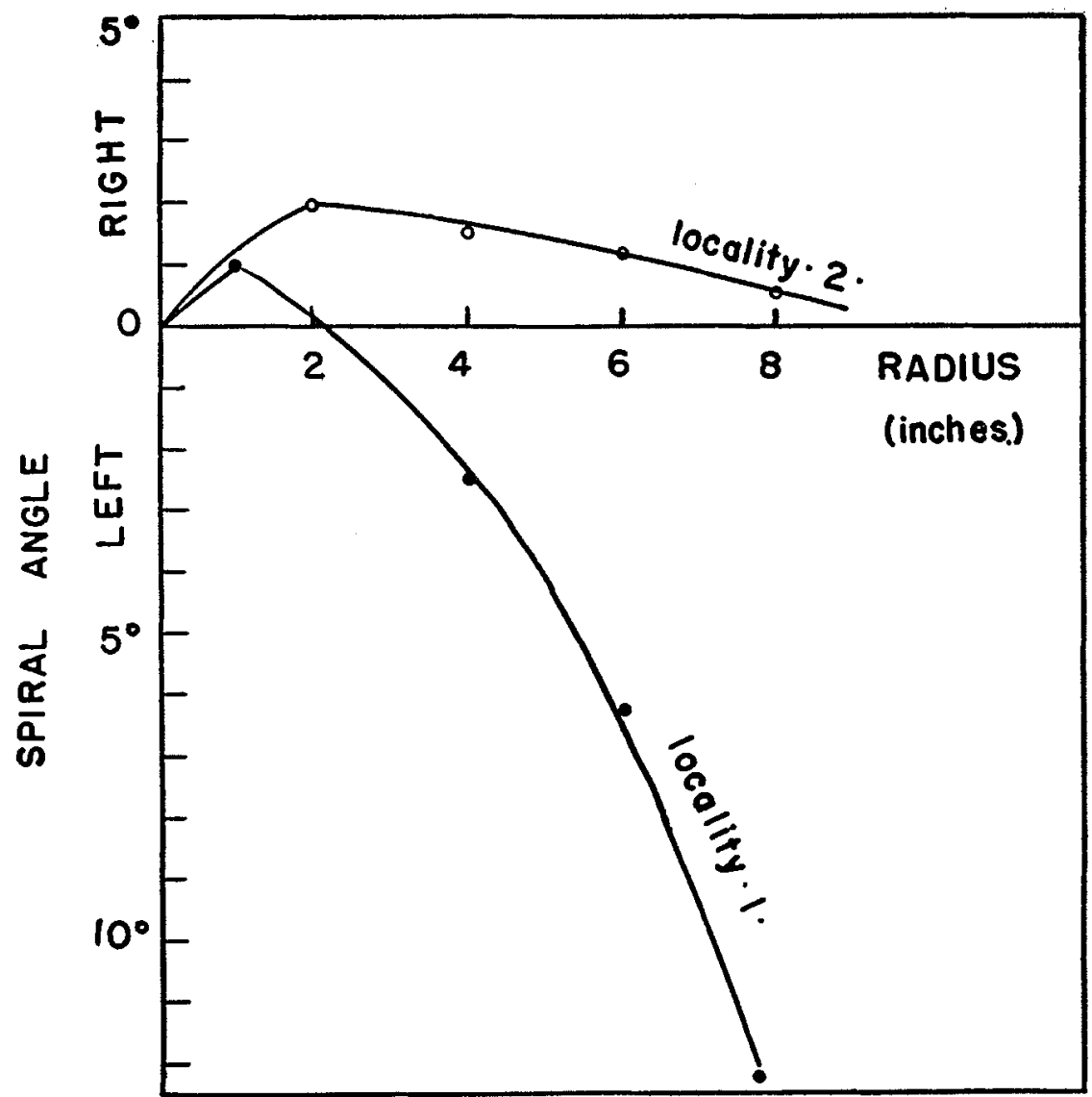

FIGURE 7. Relation Between Actual Spiral Angle And Radius for Average Trees At Breast Height.

\section{Conclusions}

The role that heredity may have in producing spiral grain was not considered in this study. Champion (1) and, more recently, Kadambi and Dabral (4) have shown that the tendency for spiral to develop is inherited. It is possible that much of the observed variation of spiral angles from mean values may be attributable to genetic variability. It was observed that the degree of correlation between radius and spiral, and age and spiral, is in the same order of magnitude for both sites (Figures 3 to 6, Table 1). This similar spread of values within each site suggests itself as an indicator of the amount of variability which may be quite largely attributable to factors of heredity.

The difference in cumulative absolute spirality between Localities 1 and 
2 is largely the result of a difference in growth rate between the two sites. A lower potential spiral, therefore, can be expected from the better site (Locality 2) than from the poorer site (Locality 1 ). The general spiral pattern in both cases, however, is the same-an initial right spiral followed by an increasing left spiral. The volume of wood showing least spirality will surround the point exhibiting zero spiral, i.e., the area of change from right to left spiral deviation. From the point of view of the lumber manufacturer, it is desirable that there be a suitably low spiral in as much of the timber as possible. Since the greatest volume in a tree is located in the outer core of the wood next to the bark, this area should have the lowest actual spiral for high merchantability. In this kind of tree the point having a low spiral deviation to the left should correspond to the merchantable diameter of the tree. Assuming a 16-inch diameter, Figure 7 shows that trees from Locality 2 have considerably less actual spiral than those from Locality 1 at this diameter. The trees from Locality 2 have an area of zero spirality corresponding to a 16 -inch diameter, whereas the Locality 1 trees have this desirable zone at a diameter of only 4 inches, far below the requirements for merchantability.

From a silvicultural point of view, it would seem that attempts should be made to control the rate of growth so that at merchantable diameter, the outer core of the tree will contain as small an amount of actual spiral as possible.

\section{REFERENCES}

1. CHAMPION, H. G. 1925. Contributions toward a knowledge of twisted fibre in trees. Ind. For. Rec. 11: 11-70.

2. FISHER, R. A. and FRANK YATES. 1949. Statistical table for biological agricultural and medical research. Hafner Publishing Co., New York.

3. Forest Club, University of British Columbia. 1953. Forestry handbook for British Columbia.

4. KADAMBI, K. and S. N. DABRAL. 1955. On twist in chir (Pinus Longifolia Roxb.). Indian Forester 81: 58-64.

5. SMITH, J. G. and A. J. DUNCAN. 1944. Elementary statistics and applications. McGrawHill Bonk Co., New York.

6. WANGAARD, F. F. 1950 . The mechanical properties of wood. John Wiley \& Sons, Inc., New York. 